\title{
Application of Trichoderma spp. Restoration in Soil Health
}

\author{
Manish Kumar ${ }^{1}$, Pramod Kumar Fatehpuria ${ }^{1 *}$, Syed Kamran Ahmad ${ }^{2}$, \\ Arshi Jamil ${ }^{2}$ and Naresh Dhakar ${ }^{3}$
}

${ }^{1}$ Department of Plant Pathology, School of Agriculture, ITM University, Gwalior, Madhya Pradesh, India

${ }^{2}$ Department of Entomology, School of Agriculture, ITM University, Gwalior, Madhya Pradesh, India

${ }^{3}$ Department of Plant Protection, Faculty of Agricultural Sciences, Aligarh Muslim

University, Aligarh, Uttar Pradesh, India

*Corresponding author

\section{A B S T R A C T}

\begin{tabular}{|l|}
\hline K e y w o r d s \\
$\begin{array}{l}\text { Contamination of } \\
\text { soil, Biocontrol } \\
\text { agents } \\
\text { Trichoderma, } \\
\text { Heavy metals }\end{array}$ \\
\hline Article Info \\
\hline $\begin{array}{l}\text { Accepted: } \\
\text { 20 January } 2020 \\
\text { Available Online: } \\
\text { 10 February } 2020\end{array}$ \\
\hline
\end{tabular}

The rampant uses of chemical pesticides by developing countries not only pollute the soil, also problem to environment and human. The current scenario is pollution of soil contaminated with heavy metals(HMs). Contamination of soil bad impact on both yields and crop qualities leads to decrement of agriculture productivity. The pathogen inhabitant in soil also responsible for contamination of soil. Soil is dwelling place of plant pathogenic fungi which cause diseases to the crops. Among the fungal biocontrol agents Trichoderma spp. are being used most abundantly against plant pathogens. Several species of Trichoderma produce volatile and nonvolatile antibiotics and enzymes. They are antagonistic to phytopathogenic fungi and nematodes. Trichoderma spp. is free-living and abundantly present in the soil and rhizosphere region, they mycoparasites several soilborne plant pathogens. Trichoderma spp. helps to concentrate and absorb heavy metals (HMs), it acts as hyper accumulator. It helpsin breaking down of various toxic substances for sustain soil health. Trichoderma spp. have great potential against soil borne pathogens, and it may be able to replace chemical pesticides in the near future.

\section{Introduction}

Chemical pesticides are abundantly used by farmers in the developing countries, polluting soil and water leading health problem to human and animals (Forget, 1993; Igbedioh, 1991). Soil microbes are capable of both directly and indirectly influencing the 
productivity, composition, and diversity of plant communities (Barea et al., 2002; Fitzsimons and Miller 2010; Lau and Lennon 2011; van der Heijden et al., 2006, 2008). These pesticides deteriorate the microbial community of the soil. India is the second largest manufacturer of pesticides inAsia after China and ranks twelfth globally (Mathur, 2010; Bhardwaj and Sharma, 2013). Biocontrol agents (BCAs) like Trichoderma spp. are the promising means that can replenish nutrient demands of the plants through various ways.

For the management of plant diseases, integrated approach of BCAs with reduced doses of chemicals have been suggested to manage plant pathogens resulting in minimal impact of the chemicals have on the environment (Chet and Inbar, 1994; Harman and Kubicek, 1998). The mechanism involvessuch as mycoparasitism, competition and production of growth enhancer molecules which promote plant growth and development.

It helps fight against soil borne pathogens. Remediation deals with the removal of pollutants from contaminated soil and support conservation of natural resources. Trichoderma spp. plays an important role in restoration of soil health by mycoremediation, secretion of certain enzymes help in decomposition of hazardous chemicals into nontoxiccompounds (Barry et al., 1994).

\section{Soil health}

Karlen et al., (1997) defined soil as the "capacity of a soil to function within ecosystem boundaries for sustainable plantanimal productivity. This leads to maintain human health habitation. Richness of species within the soil microbiome help in producing high functional inclusion allowing quickly recover during stress (Nannipieri et al., 2003;
Yin et al., 2000). The soil microbial diversity also endow with protection against soil-borne diseases (Brussaard et al., 2007; Garbeva et al., 2004; Nannipieri et al., 2003). The capability of the soil microbiome plays an important role in antagonism against pathogens present in soil and helping plant productivity (Janvier et al., 2007).

During management practises manipulation of quality and quantity of organic inputs ramify the action of soil microbiome, and biological processes of nutrient transformation within the soil (Stockdale et al., 2002). Trichoderma spp. secretes lytic enzymes which act against cell wall of fungal pathogens (Sivan and Chet 1989).

\section{Mechanism}

Plant diseases results interaction among various component consist of host, pathogen and environment i.e. diseases triangle. BCAs are the organism manage diseases by the interaction various components of diseases triangle. BCAs involve several types of mechanisms in achieving disease control. However, the conclusive evidences for the involvement of a particular factor in biological control are determined by the strict correlation between the appearance of factor and the biological control (Handelsman et al., 1989).

\section{Mycoparasitism}

Mycoparasitism is one of the main mechanism against the target organism by coiling and dissolution of target pathogens cell wall through enzymatic activity (Tiwari 1996; Sharma 1996). Trichoderma harzianum exhibits excellent mycoparasitic activity against Rhizoctonia solani hyphae (Altomareet al.1999). Mycoparasitism having enzymatic activity which are anagonist to pathogen. Harman (2000) reported the 
involvement of chitinase and $\beta-1,3$ glucanase in the Trichoderma mediated as biocontrol agents. Gupta et al., (1995) reported that a strain of Trichoderma deficient in the ability to produce endochitinase had reduced ability to control Botrytriscineriabut shows increased ability to control Rhizoctonia solani.

\section{Competition}

Interaction between the pathogen and the bioagents compete for the nutrients and space to get them established in the environment while pathogens are excluded by the depletion of food base and physical occupation of site (Loritoet al., 1994). BCAs compete with essential micronutrients such as iron and manganese especially in highly oxidized and aerated soils. BCAs are more efficient in the nutrient utilisation and compete with the pathogens (Nelson 1990).

The production of iron binding ligands called siderophores as in Erwiniacaratovora. Siderophoreschealate $\mathrm{Fe}$ (II) ions and the membrane bind protein receptors recognize and take up the Siderophore-Fe-complex (Mukhopadhyay and Mukherjee 1998). It makes iron unavailable to the pathogen, which produce less siderophores with lower binding power and causes less pathogenic infection. These substance acts as stimulant to overcome dormancy and exert competition and help in reducing disease causing ability.

\section{Trichoderma against soil borne pathogen}

Pathogens associated with soil having a wide host range which persists for longer period as resting resistant structures. Soil borne pathogens control by chemicals but there are also adverse effects on environment as well as affecting the beneficial soil microorganisms. Trichoderma spp. is used as fungal biological control agent commonly have been known effective antagonists against plant pathogenic fungi (Chet et al., 1981; Papavizas 1985; Chet 1987; Kumar and Mukerji 1996). The inhibitory activity of Trichoderma harzianum, $T$. viride and $T$. virens against soil borne fungal pathogens has been reported (Dohroo et al., 1990; Abdollahzadeh et al., 2003). The mechanism involves either through antibiosis or mycoparasitism due to competition for space, nutrition between the pathogens and the antagonist. They also produce antifungal phenolic compounds which inhibit plant pathogen (Banday et al., 2008).

\section{Trichoderma as bioremediator}

Trichoderma is soil borne fungi plays an important role in the bioremediation of contaminated soils and can be applied in integrated pest management and phytoremediation. They also have known to enhance plant growth and development. BCAs help in promoting growth of the plants, as well as improvement of soil fertility, disease suppression and composting (Contreras-Cornejo et al.2009).

Trichoderma spp.is a producer of organic acids such as gluconic acid, fumaric acid, and citric acid, which help in reducing soil $\mathrm{pH}$, promote phosphate dissolution, dissolution of macro and micronutrients such as iron, manganese, and magnesium that necessary for plant metabolism. Moreover, it can remove and concentrate the various ions such as $\mathrm{Pb}$, $\mathrm{Cd}, \mathrm{Cu}, \mathrm{Zn}$, and $\mathrm{Ni}$ widely recognised as the main mechanism of uptake (Srivastava etal. 2011). Trichoderma apply in facilitating metal stress tolerance in plants imputed to improve root biomass and enhanced nutrient availability and efficiency (Arriagadaetal. 2009; Mastouriet al., 2010).

\section{Mycoremediation of inorganic pollutants by Tricoderma spp.}

Contaminants like HMs from sewage sludge 
which cannot be destroy easily, they live in soil for a long period of time. It makes soil unfertile and uneasy for farmer to grow crops. HMs like cadium, mercury, copper, zinc and arsenic increasingly released in the environment by the use of pesticides, fertilizers and other anthropogenic activities (Errasquin and Vazquez 2003; Tripathi et al., 2007).Fungi like Trichoderma spp. play an important role to degrade and detoxify toxic substances. Kredics et al., (2001) reported that four Trichoderma isolates out of 13 tested against $\mathrm{Ni}$, As, and $\mathrm{Zn}$ possessed an effective soil colonization and showed high biodegradation potential.

\section{Mycoremediation of organic pollutants by Tricoderma spp.}

Organic chemicals such as Polycyclic aromatic hydrocarbons (PAHs) are potent environmental pollutants which consist of three or more fused benzene ring in linear. PAHs are sparingly soluble, hydrophobic, and strongly bound to soil particles. They damage genetic materials and change the structure of cells (Pashin and Bakhitova 1979). The techniques such as biostimulation, bioagumentation, areration and turning or combining these practices help in bioremediation. The substrate of bioremediator which act upon bio waste and contaminated soil (Alexander 1994). The responses of 25 Trichoderma spp. are reported against PAHs.

Among them Trichoderma longibractum proved more tolerant than other strain (Oros et al., 2011). The fungus Trichoderma was identified as dominant in the dieselcontaminated compost, which have the potential to colonize and help in degradation ofdiesel-contaminated soil (Hajieghrari 2010). Mishra and Nautiyal (2009) demonstrated Trichodermaressei having potential to promote plant growth in soil with diesel as pollutant.

\section{Mycoremediation of agrochemicals by Tricoderma spp.}

Repeated use of pesticides in a frequent manner makes field unfit for agricultural practises Agrochemicals accumulation in the environment is major concern for growers as well as environmentalist. Unused pesticides solution having organic compounds run off directly into the soil becomes worrying situation. These xenobiotics exert harmful consequences to human health. Moreover, these chemical are responsible for decreasing population of microbiome.

The microbiome in the soil helps to fight against pathogens and promote growth and development of plants. Removals of pesticides become cumbersome for scientific community. Conventional treatment appears inefficient (Badawy et al., 2006). Trichoderma are able to biodegrade toxic pollutant efficiently (Harman et al., 2004b; Cao et al., 2008). Extracellular enzymes system of the fungi and their catalytic reaction help to degrade toxic aromatic compounds. Trichodermaviride was reported most efficient among tested fungi for the degradation of chlorpyrifos and photodieldrin (Tabet and Lichtenstein 1976; Mukherjee and Gopal 1996). Integrated management strategy having Trichoderma spp. are combined with pesticides help in remediation of contaminated sites and reducing the chemical load for clean environment.

It is concluded that BCAs Trichoderma having complicated interactions between advantageous microbes, established a relationship among plants, pathogens and the soil ecosystem. Fungicides control pathogens effectively, but they pollute soil and water causing harm to human health. For the protection of plants and their crop yield 
Trichoderma spp. is best and safer option. Recent advancement of modern techniques and less expensive methods to protect plants and increase crop yield have drawn the attention of growers. Genetic manipulation offers opportunity to achieve improve biocontrol efficacy.

The application of Trichoderma metabolites help in protection of crop, by host defence inducers and antibiotics. There is an availability of numerous technologies for environment cleaning, each having its advantages and limitations for the treatment of specific pollutants. Mycoremediation is an innovative approach having a potential to diminish numerous environmental contaminants problems.

The Trichoderma are diverse species are tolerant to wide range of refractory pollutants including HMs, pesticides, and polyaromatic hydrocarbons. They are safe, environment friendly and can be easily used by farmers. However, it needs more work to be done to develop cost-effective, stable, and easy to apply formulations.

\section{References}

Abdollahzadeh J, Mohammadi GE, Rouhani $\mathrm{H}$ (2003) Evaluation of antagonistic effect of trichoderma species in biological control of causal agent of crown and root rot of sunflower (sclerotinia minor) in vitro 13:23

Ahamed A, Vermette P (2009) Effect of culture medium composition on Trichodermareesei's morphology and cellulase production. BioresTechnol 100:5979-5987

Alexander M (1994) Biodegradation and bioremediation. Academic Press, New York

Altomare C, Norvell WA, Bjorkman T, Harman GE (1999) Solubilization of phosphate and micro nutrients by the plant growth promoting fungus Trichoderma harzianum Riafi. Applied Environmental Microbiology. 65: 2926-2933

Arriagada C, Aranda E, Sampedro I, GarciaRomera I, Ocampo JA (2009) Contribution of the saprobic fungi Trametesversicolor and Trichoderma harzianum and the arbuscular mycorrhizal fungi Glomus deserticola and $\mathrm{G}$. claroideum to arsenic tolerance of Eucalyptus globules. BioresTechnol 100:6250-6257

Badawy MI, Ghaly MY, Gad-Allah TA (2006) Advanced oxidation processes for the removal of organo phosphorus pesticides from wastewater. Desalination 194:166-175

Banday S, Dar GH, Fatima N (2008) Influence of biocontrol agents on plant growth and white root rot of apple. Plant Disease Research, 23(2), 46-50

Barea JM, Azcon R, Azcon-Aguilar C (2002) Mycorrhizosphere interactions to improve plant fitness and soil quality. Anton LeeuwInt J G 81:343-351

Barry DP, Austa SD (1994) Pollutant degradation by white rot fungi, Review of environmental contamination and Toxicology $138: 49-72$.

Bhardwaj, T., \& Sharma, JP (2013) Impact of pesticides application in agricultural industry: An Indian scenario. International Journal of Agriculture and Food Science Technology, 4(8), 817-822.

Brussaard L, de Ruiter PC, Brown GG (2007) Soil biodiversity for agricultural sustainability. AgrEcosyst Environ 121:233-244

Cao L, Jiang M, Zeng Z, Du A, Tan H, Liu Y (2008) Trichodermaatroviride F6 improves phytoextraction efficiency of mustard [Brassica juncea (L.) 
Coss.var. foliosa Bailey] in $\mathrm{Cd}, \mathrm{Ni}$ contaminated soils. Chemosphere 71:1769-1773

Chet I (1987) Trichoderma-Application, mode of action, and potential as a biocontrol agent of soilborne pathogenic fungi. Pages 137-160 in: Innovative Approaches to Plant Disease Control. I. Chet, ed. John Wiley \& Sons, New York.

Chet I, Baker R(1981) from Soil Naturally Suppressive to Rhizoctonia solani. Phytopathology 71:286-290.

Chet I, Inbar J(1994) Biological control of fungal pathogens. Applied biochemistry and biotechnology 48(1):37-43

Contreras-Cornejo HA, Macias-Rodriguez L, Cortes- Penagos C, Lopez-Bucio J(2009) Trichoderma virens, a plantbeneficial fungus, enhances biomass production and promotes

Dohroo NP, Gupta SK, Shyam KR, Sharma K(1990) Antagonistic studies on causal fungi of wire stem and stalk rot of cauliflower. Indian Journal of Plant Pathology 8:77-78

Errasquin EL, Vazquez C(2003) Tolerance and uptake of heavy metals by Trichoderma atroviride isolated from sludge. Chemosphere 50:137-143

Fitzsimons MS, Miller RM(2010) The importance of soil microorganisms for maintaining diverse plant communities in tallgrass Prairie. Am J Bot 97:1937-1943

Forget G. Balancing the need for pesticides with the risk to human health. In: Forget G, Goodman T, de Villiers A, Impact of Pesticide Use on Health in Developing countries. 1993. IDRC, Ottawa: 2.

Garbeva P, van Veen JA, van ElsasJD(2004) Microbial diversity in soil: selection microbial populations by plant and soil type and implications for disease suppressiveness. Annu Rev

Phytopathol 42:243-270

Gupta S, Arora D K, Shrivastava A K(1995). Growth promotion of tomato plants by Rhizobacteria and imposition of energy stress on Rhizoctonia solani. Soil Biology and Bio chemistry. 27: 1051-1058

Hajieghrari B(2010) Effect of some metalcontaining compounds and fertilizers on mycoparasite Trichoderma species mycelia growth response. Afr J Biotechnol 9:4025-4033

Handelsman J, ParkeJL(1989) Mechanisms of biocontrol of soilborne plant pathogens. Plant-microbe interactions (USA)

Harman GE(2000) Myths and dogmas of Bio control : Changes in the perceptions derived from research on Trichoderma harzianumT-22. Plant Disease.84: 377-393

Harman GE, Kubicek CP(1998) Trichoderma and Gliocladium. Volume 2: Enzymes, biological control and commercial applications. Taylor and Francis Ltd

Harman GE, Howell CR, Viterbo A, Chet I, LoritoM(2004a) Trichoderma speciesopportunistic, avirulent plant symbionts. Nat Rev Microbiol 2:4356

Harman GE, Lorito M, Lynch JM(2004b) Uses of Trichoderma spp. to remediate soil and water pollution. AdvApplMicrobiol 56:313-330

Igbedioh, SO(1991). Effects of agricultural pesticides on humans, animals, and higher plants in developing countries. Archives of Environmental Health: An International Journal, 46(4), 218-224.

Janvier C, Villeneuve F, Alabouvette C, EdelHermann V, Mateille T, Steinberg C(2007) Soil health through soil disease suppression: which strategy 
from descriptors to indicators? Soil BiolBiochem 39:1

Karlen DL, Mausbach MJ, Doran, JW., Cline, R.G., Harris, R.F., Schuman, GE (1997) Soil quality: a concept, definition, and framework for evaluation (a guest editorial). Soil Sci. Soc. Am. J 61:4-10

Katayama A, Matsumura F(1993) Degradation of organochlorine pesticides, particularly endosulfan, by Trichoderma harzianum. Environ ToxicolChem 12:1059-1065

Kredics L, Antal L, Manczinger L, Nagy E (2001) Breeding of mycoparasitic Trichoderma strains for heavy metal resistance. LettApplMicrobiol 33:112116

Kumar S, Mukerji KG, Lai R(1996) Molecular aspects of pesticide degradation by microorganisms. Critical reviews in microbiology 22(1): 1-26

Lau JA, Lennon JT(2011) Evolutionary ecology of plant-microbe interactions: soil microbial structure alters selection on plant traits. New Phytol 192:215224

Lorito M, Hayes C K, Zonia A, Scala F, Del SG, Woo SL, Harman G E(1994) Potential of genes and gene products from Trichoderma sp. And Gliocladium sp. for the development of biological pesticides. Molecular Biotechnology.2: 209- 217

Mastouri F, Bjorkman T, Harman GE(2010) Seed treatment with Trichoderma harzianum alleviates biotic, abiotic, and physiological stresses in germinating seeds and seedlings. Phytopathology 100:1213-1221

Mathur SC. Future of Indian pesticides industry in next millennium.Pesticide Information. 2010; 24 (4):9-23.

Mishra A, NautiyalCS(2009) Functional diversity of the microbial community in the rhizosphere of chickpea grown in diesel fuelspiked soil amended with Trichoderma ressei using solecarbonsource utilization profiles. World J MicrobiolBiotechnol 25:1175-1180

Monteiro VN, Ulhoa CJ(2006) Biochemical characterization of a b- 1,3-glucanase from Trichoderma koningii induced by cell wall of Rhizoctonia solani. CurrMicrobiol 52:92-96

Mukherjee I, Gopal M(1996) Degradation of chlorpyrifos by two soil fungi Aspergillus niger and Trichoderma viride. Toxicol Environ Chem 57:145151

Mukhopadhyay ASN, Mukherjee PK(1998) Biological control of plant diseases: status in India in Biological suppression of Plant Diseases: Phytopathogens, Nematodes and weeds. Eds. Singh, S. P. and Husain, S. S. 7: $1-20$

Nannipieri P, Ascher J, Ceccherini MT, Landi L, Pietramellara G, Renella G (2003) Microbial diversity and soil functions. Eur J Soil Sci 54:655-670

Nelson EB(1990) Exudate molecules initiating fungal responses to seed seeds and roots. Plant and Soil 129: 61-73

Oros G, Naar Z, CserhatiT(2011) Growth response of Trichoderma species to organic solvents. MolInf 30:276-285

Papavizas GC (1985) Trichoderma and Gliocladium: biology, ecology, and potential for biocontrol. Annual Review Phytopathology 23:23-54

Pashin YV, BakhitovaLM(1979) Mutagenic and carcinogenic properties of polycyclic aromatic hydrocarbons. Environ Health Pers 30:185-189

Sharma G(1996) Studies on the integrated management of banded leaf and sheath blight of maize caused by Rhizoctonia solani, M.Sc (Ag.), thesis 
submitted to G.B. Pant University of Agriculture and Technology, Pantnagar, India pp65

Sivan A, Chet I(1989) Degradation of fungal cell walls by lytic enzymes of Trichoderma harzianum. J Gen Microbiol 135:675- 682

Srivastava PK, Vaish A, Dwivedi S, Chakrabarty D, Singh N, Tripathi $\mathrm{RD}(2011)$ Biological removal of arsenic pollution by soil fungi. Sci Tot Environ 409:2430-2442

Stockdale EA, Shepherd MA, Fortune S, Cuttle SP(2002) Soil fertility in organic farming systemsfundamentally different? Soil Use Manage 18:301-308

Tabet JC, Lichtenstein EP(1976) Degradation of $[14 \mathrm{C}]$ photodieldrin by Trichoderma viride as affected by other insecticides. Can J Microbiol 22:1345-1356

Tiwari AK (1996) Biological control of chick pea wilt complex using different formulations of Gliocladium virens through seed treatment. Ph.D. thesis submitted to G. B. Pant University of Agriculture and Technology, Pantnagar, India pp167

Tripathi RD, Srivastava S, Mishra S, Singh N, Tuli R, Gupta DK, Maathuis FJM (2007) Arsenic hazards: strategies for tolerance and remediation by plants. Trends Biotechnol 25:158-165

van der Heijden MGA, Bakker R, Verwaal J, Scheublin TR, Rutten M, Van Logtestijn R, Staehelin C(2006) Symbiotic bacteria as a determinant of plant community structure and plant productivity in dune grassland. FEMS MicrobiolEcol 56:178-18

van der Heijden MGA, Bardgett RD, Van Straalen NM (2008) The unseen majority: soil microbes as drivers of plant diversity and productivity in terrestrial ecosystems. EcolLett 11:296-310

Yin B, Crowley D, Sparovek G, De Melo WJ, Borneman J (2000) Bacterial functional redundancy along a soil reclamation gradient. Appl Environ Microbiol 66:4361-4365

\section{How to cite this article:}

Manish Kumar, Pramod Kumar Fatehpuria, Syed Kamran Ahmad, Arshi Jamil and Naresh Dhakar. 2020. Application of trichoderma spp. Restoration in soil health. Int.J.Curr.Microbiol.App.Sci. 9(02): 3051-3058. doi: https://doi.org/10.20546/ijcmas.2020.902.351 